\title{
Visualidades contempoprâneas com Pina Bausch e Madonna: outros modos dos corpos (se) (mo)verem
}

\section{Resumo:}

Este artigo visa relacionar fragmentos e imagens de performances culturais produzidas pela coreógrafa/artista Pina Bausch e pela cantora/artista Madonna, aqui compreendidos como visualidades contempoprâneas. Assumindo a perspectiva da cultura visual e, portanto, não estabelecendo hierarquia entre imagens, este estudo faz uma reflexão a partir das categorias corpo, afeto e prazer, articulando uma perspectiva pedagógica por meio da qual é possível reconhecer o investimento afetivo de educandos e educadores nas relações que estabelecem com artefatos culturais, sejam eles considerados populares, eruditos ou de massa.

Palavras chave: visualidades contempoprâneas, corpo, pedagogia, Pina Bausch, Madonna.

\section{Abstract:}

This article focuses on crossovers between fragments of cultural performances produced by the choreographer/artist Pina Bausch and the singer/artist Madonna, understanding both as contempoprary visualities. Taking a visual culture perspective and, as so, not establishing hierarchies among images, this study reflects on the categories of body, affection and pleasure, articulating a pedagogical perspective through which is possible to recognize the affective investment of students and teachers in the relationships they establish with cultural artifacts, wherever they are considered popular, erudite or mass products.

Key words: contempoprary visualities, body, pedagogy, Pina Bausch, Madonna.

Neste artigo tecemos relações, divergências e convergências entre imagens e fragmentos do espetáculo de dança contemporânea "Água" (2001) da coreógrafa alemã Pina Bausch (1940-2009) e do show pop "MDNA Tour" (2012) da cantora norte-americana Madonna. As motivações que nos levam a escolher as referidas artistas e suas performances culturais como foco deste estudo, estão ligadas às nossas experiências pessoais de prazer, afeto, consumo e uso dessas imagens. Nossa motivação também está embasada em interesses 
de pesquisa na educação da cultura visual, campo que ao não hierarquizar imagens, trabalha com um repertorio diversificado de visualidades, produtos e artefatos culturais.

Os fragmentos e imagens do espetáculo "Água", além da experiência de tê-lo assistido ao vivo e da busca de vídeos no site youtube

(http://www.youtube.com/watch?v=YLQIf6cFPpU) e outros, advém das descrições do catálogo "Pina Bausch", de Fábio Cypriano (2005). O referido catálogo apresenta um mapeamento simbólico da abordagem da coreógrafa ao confrontar elementos da cultura brasileira para a criação do referido espetáculo. Tendo acompanhado pessoalmente a visita de Bausch e seus dançarinos ao Brasil, Cypriano (2005) descreve a trajetória dela pela cidade de Salvador/BA e apresenta elementos de sua própria experiência enquanto espectador diante da estreia do espetáculo que resultou, segundo ele, num modo particular de dança. As imagens e fragmentos do show "MDNA Tour", além de assistidos ao vivo, foram capturados no site youtube

(http://www.youtube.com/watch?v=Sectz16ssI8) e outros. Nosso intuito é compreender, por meio da educação da cultura visual, desafios de trabalhar pedagogicamente com artefatos visuais e modos como eles podem enfatizar relações entre corpo, prazer e afeto.

O percurso que desenhamos ao longo deste texto apresenta, primeiramente, de modo descritivo, os fragmentos do espetáculo "Água" e do show "MDNA Tour". Tais fragmentos são analisados indicando os elementos que destacamos e os modos como compreendemos as categorias corpo, prazer e afeto nestes contextos. Na sequência, a reflexão delineia diálogos e cruzamentos entre aportes teóricos, imagens e nossas experiências.

\section{Mística, festa e sensualidade nas águas de Pina Bausch}

Cypriano (2005) analisa o espetáculo "Água" por meio de sete núcleos simbólicos do elemento água: águas claras, águas que vinculam, águas místicas, águas festivas, águas mornas, águas sensuais e águas energizantes. Para esta reflexão, nos deteremos em alguns elementos das águas místicas, festivas e sensuais, entendendo esses núcleos como mais diretamente afeitos às dimensões que definimos: corpo, afeto e prazer.

Em águas místicas, como descreve Cypriano (2005), o cenário é composto por projeções de plantas verdes, uma floresta que remete ao imaginário do Paraíso. Como espectador diante do espetáculo, o autor relata suas sensações e pensamentos: "A impressão é de que há algo a ser revelado, mais profundo, que as projeções não dão conta" (p. 128). Mais adiante, uma das dançarinas, sentada numa cadeira, é segurada pelos ombros e movida de modo que sua cabeça gire. Todo o elenco entra no palco e repete a mesma sequência 
de movimentos de modo que "inicia-se um ritual" onde "todos parecem tomar parte de um transe" (p.128).

Como o dançarino Strecker relatou ao autor, o espetáculo traz marcas fortes resultantes da visita ao Brasil. Segundo ele, Bausch fez questão de criar determinados climas no espetáculo "que são como um transe, momentos de grande envolvimento e seriedade, de religiosidade". Isso tem a ver, continua o dançarino, "com os lugares que estivemos na Bahia: as igrejas e os terreiros" (CYPRIANO, 2005, p. 129). Com as águas místicas ou religiosas, percebemos que Bausch transpõe ao palco com sutileza, significados, impressões, imagens e gestos vistos no candomblé, todavia, sem qualquer caricatura. 0 autor comenta, ainda, que, por meio das ações de saltar, elevar, escalar e flutuar, "a liturgia que se vê no palco" (p. 131) sugere sentidos de ascensão, suspensão, incorporação, próximos daquilo que demonstram/manifestam grande parte dos rituais religiosos.

O núcleo das águas festivas inicia com uma referência a Iemanjá, projetando uma jangada com pecadores em alto-mar. O palco está todo branco, interrompido apenas por um imenso galho suspenso contendo folhas de bananeira. Oito grandes sofás, também brancos, estão dispostos no espaço. Vestindo trajes de banho, todos os dançarinos estão sentados. Cypriano (2005) comenta que esse ambiente lembra as estufas francesas do início do século XVI, "espaços de excesso e transgressão". As "águas festivas [...] propiciam a festa do corpo" (p. 132), onde, como em um clima carnavalesco, um calor amolece os corpos. Águas aquecidas aumentam a sensibilidade do corpo e, como no carnaval, intensificam o simbolismo da festa entendida como desregramento, sublimação, transgressão, um modo de aceitação, vivência e expressão dos desejos.

As águas festivas tratam da visibilidade do corpo. Cypriano (2005) relata que os dançarinos "transformam seus corpos com toalhas, ganham contornos sensuais, novos rostos, trocam de sexo", contracenando tanto a liberação do corpo quanto a obsessão por imagens ideais e perfeitas do corpo, imagens de transgressão e de coerção (p. 133).

Sobre o núcleo das águas sensuais, Cypriano (2005) comenta que Bausch elabora um mosaico de relacionamentos que acontecem de várias maneiras, como um "mapeamento de afetos" (p. 137): casais orgulhosos, brigando, gemendo, interagindo. Mais adiante, o movimento dos dançarinos, mesclado à projeção de muitos pássaros voando, cria imagens que, segundo o autor, ressaltam a intenção de Bausch em abordar uma "noção do belo enquanto estímulo de prazer", o que ele destaca como algo fundamental na produção artística (p. 138). Para além de princípios estéticos, as imagens 'belas' funcionam por um princípio de prazer, no sentido de que, prossegue Cypriano (2005), "Bausch não trata do belo em si, mas de um belo que surge a partir dos sonhos, portanto, cheio de ambivalências" (p. 138). 
Nessa síntese, destacamos: das águas místicas - o ritual e a liturgia; das águas festivas a transgressão; e das águas sensuais - o afeto e o prazer. Entendemos que esses elementos estão permeados, atravessados e interligados no e pelo corpo, sujeito e lugar dessas ações, sentimentos, pensamentos: ritual e liturgia, entendidos como um conjunto de símbolos e gestos religiosos que, por mais que lhes sejam atribuídos sentidos espirituais ou sobrenaturais, são vivenciados, organizados e visualizados pelos corpos; transgressão, enquanto ação de ultrapassar, violar, ir além do permitido, no modo como aqui compreendemos, é uma ação feita por corpos rebeldes, inquietos; afeto e prazer são elementos que dizem da intensidade, dos estados e do envolvimento do corpo nas relações que estabelece com outros corpos, objetos e com o mundo. Esses elementos do espetáculo de Pina Bausch, junto com as reflexões de Shusterman (1998) sobre os desafios da arte popular e dos argumentos de Giroux (1999) acerca da cultura popular e de uma pedagogia do prazer, nos movem e, em decorrência, movem esta reflexão rumo a determinados elementos presentes no show "MDNA Tour" da cantora norte-americana Madonna. Como elementos do trabalho de Pina Bausch podem ser relacionados com fragmentos do show de Madonna?

\section{Mística, festa e sensualidade na "missa" de Madonna}

Desde a estreia em 31 de maio de 2012, na cidade de Tel Aviv, Israel, as muitas imagens, em movimento e estáticas, no site youtube e em vários outros, já davam a ver, ao mundo, trechos do último show da cantora Madonna, muito antes da apresentação ao vivo. O show inicia num palco que é uma imensa catedral gótica. Entram monges vestidos com túnicas e capuzes bordô para tocar os sinos que dão início à liturgia. Ao soar dos sinos, desce um grande turíbulo dourado, regado pelos monges com essências aromáticas que vão incensar a assembleia para o início da celebração. O turíbulo é balançado e erguido, girando sobre a plateia que vibra eufórica diante do ato ao mesmo tempo sacro e profano.

O ritual prossegue com outros monges cantores, vestidos de preto e branco, que emergem do chão para entoar uma espécie de canto gregoriano ou ladainha com o nome Madonna. Enquanto isso, rastejando, dançarinos vestidos como gárgulas surgem e se postam sobre módulos elevados realizando poses e movimentos coreográficos com contorções. Uma voz feminina (de Madonna) inunda o ambiente emitindo, repetidamente, em tom de súplica: "Oh, my God!" O público vibra e manifesta-se aos gritos, quase que numa louvação. Os monges vestidos de bordô, agora enfileirados diante da plateia, se põem de joelhos e fazem o sinal da cruz. As portas da catedral se abrem e surge um imenso oratório suspenso denotando a silhueta de uma mulher ajoelhada rezando, de mãos postas, a oração do ato de contrição. Ao fim da prece, a mulher se levanta, empunha um rifle que já se mostrava 
junto à sua silhueta e quebra o vidro do oratório. Este ato faz quebrar os vitrais da imensa catedral construída por projeções.

O oratório desce e aproxima a imagem de uma santa vestida de preto, adornada com uma

coroa dourada. É a própria Madonna literalizando o significado do seu nome - no idioma italiano - Nossa Senhora. A plateia fica ensandecida. Madonna tira o véu e a coroa e sai do oratório entoando a canção "Girl Gone Wild", hit do seu recente disco "MDNA" (2012), seguida pelo imenso coro da multidão. Os monges a acompanham na coreografia e, aos poucos, vão tirando os capuzes e abrindo as túnicas, mostrando seus corpos bem definidos e cobertos, agora, apenas por calças legging pretas e longos rosários enfeitando seus peitos desnudos. Eles calçam sapatos de salto alto, dançam uma coreografia estruturada por movimentações e gestualidades queer (no caso, gay). São corpos másculos movendose de modo provocante e afeminado, conforme faz o grupo masculino ucraniano "Kazaky" que participa do music video desta mesma canção.

A partir dos elementos apresentados acima, percebemos que existem claras diferenças no processo de criação de Madonna e Pina Bausch, além de diferenças nos modos de inserção dos referidos produtos no mercado artístico e cultural. A alemã Pina Bausch fazia dança contemporânea, produto artístico considerado como pertencente à alta cultura, raramente visto nos meios midiáticos, de complexa compreensão, restrito a um público seleto, pouco acessível à maioria da população, propagado de um modo circunscrito. A norte-americana Madonna pode ser apreciada como uma figura da indústria cultural, autora de música pop, produto da cultura de massa, presente no cotidiano da maioria das pessoas por meio das mais variadas formas de inserção e propagação de imagens, comerciais, produtos e artefatos culturais. Isso seria um dos modos mais corriqueiros de se entender e ver estas artistas. Todavia, para aprofundar a discussão, destacamos, nos trabalhos de ambas, pontos de entrecruzamentos reflexivos no que tange às questões da mística (ritual e liturgia), festa (transgressão), sensualidade

(afeto e prazer). Com esses elementos buscamos refletir sobre as seguintes questões: Como estes produtos culturais se entrelaçam com práticas cotidianas dos corpos? Como esses artefatos visuais interpelam estética e afetivamente os corpos? Como pensar-fazer uma pedagogia com tais artefatos a partir de proposições da educação da cultura visual?

\section{Sobre corpo, afeto e prazer}

Para articular as reflexões do presente estudo, nos apoiamos em compreensões que buscam não mais ver corpo, afeto e prazer como prisões da alma, como lugar de 
percepções errôneas ou, de pecado. Corpo, para Greiner e Katz (2001), é um "contínuo entre o mental, o neuronal, o carnal e o ambiental" (p. 70). O corpo se constrói e é construído nas trocas, interações e relações estabelecidas com o ambiente, com a cultura. As autoras dizem ainda que "no corpo humano estão as evidências da inevitabilidade de ser contaminado e contaminador" (2001, p. 72). O corpo é biológico e cultural ao mesmo tempo, de modo que é possível - e necessário - entende-lo como trânsito entre natureza e cultura.

Lakoff e Johnson (1999) entrecruzam ciência cognitiva e filosofia afirmando que a razão não se dá separada da experiência e do movimento corporal como a tradição ocidental tem afirmado. Os mesmos procedimentos corporais que nos permitem ver, perceber, sentir e nos mover, criam nossos modos de raciocinar, pensar, interpretar, categorizar e significar. Embora certas concepções modernas afirmem que o conhecimento independe dos sentidos, supervalorizando o saber inteligível em detrimento do saber sensível, todo conhecimento é sensível e inteligível ao mesmo tempo. Isso é o que os autores chamam de uma filosofia na carne, onde o conhecimento é constituído na indissociabilidade que há entre natureza e cultura e entre os procedimentos sensório-motores e conceitualabstratos do corpo - aqui entendido como "corpomídia":

O corpo não é um meio por onde a informação simplesmente passa, pois toda informação que chega entra em negociação com as que já estão. O corpo é o resultado desses cruzamentos, e não um lugar onde as informações são apenas abrigadas. É com esta noção de mídia de si mesmo que o corpomídia lida, e não com a ideia de mídia pensada como veículo de transmissão. A mídia à qual o corpomídia se refere diz respeito ao processo evolutivo de selecionar informações que vão constituindo o corpo. (GREINER; KATZ, 2005, p. 130-131).

Ao perceber-se desafiado pelas informações e imagens, eventos e fenômenos do ambiente, por meio das relações que estabelece e das quais faz parte, o corpo questiona o que já sabe, interpela a novidade, seleciona, agrega, processa, transforma em corpo a informação. Nesse processo o corpo se constrói, interfere no seu meio e também se faz imagem/informação através da qual se pode ver traços da sociedade, da história, da cultura. Em vez de corpo recipiente, como tradicionalmente se tem dito, pode ser entendido como corpomídia, contaminado e contaminador, mídia de seu tempo, de si mesmo e de sua cultura.

Neste sentido, também compreendemos as categorias prazer e afeto, utilizadas neste estudo. Com base em Espinoza, conforme comenta Chauí (2010), compreendemos afeto como aquilo que o corpo experimenta quando é afetado, tocado, envolvido, capturado, (i)mobilizado por outro corpo, um objeto, uma imagem, etc. Podemos dizer que afeto se 
refere a estados e intensidades do corpo ao se relacionar com o mundo, o ambiente, a cultura e as mais variadas formas de objetos e produtos. Acompanhando as ideias de Alves (2011), também compreendemos que prazer diz respeito ao envolvimento e investimento sensível, erótico e lúdico do corpo com outros corpos, objetos, imagens, situações que o seduzem, estimulam, atraem, afetam, que o fazem vibrar e Ihe possibilitam a criação de sentidos/significados. Essas compreensões de afeto e prazer, sentimento e pensamento, emoção e razão se entrecruzam e interagem simultaneamente, sem hierarquias ou dicotomias.

\section{Pina Bausch e Madonna: entre o 'maldito' popular e o 'bendito' erudito}

Refletindo acerca das barreiras, hegemonias, rebaixamentos e possibilidades de dissolução das dicotomias entre artes maiores e arte popular, Shusterman (1998) enfatiza a difamação exercida contra a arte popular ou a cultura de massa. Tal difamação tem sido endossada por intelectuais com diferentes visões político-sociais, desde filósofos marxistas, conservadores de direita, até defensores da arte popular com atenuantes e aniquiladoras apologias. Apoiado no pragmatismo deweyiano, Shusterman (1998) propõe uma visão crítica de suspeita em relação às divisões estabelecidas entre produtos considerados das artes elevadas e aqueles das artes populares. Um mesmo artefato, explica o autor, pode funcionar tanto como arte popular quanto como arte elevada, dependendo dos modos como é interpretado e apropriado pelas pessoas. Os modos e condições como os artefatos são apresentados/acontecem, também impactam o funcionamento desta relação, embora Shusterman não enfatize esta perspectiva.

Prosseguindo a reflexão, Shusterman (1998) comenta as opiniões de intelectuais como Adorno, Bloom, Greenberg, Van den Haag, Rosenberg, Lowenthal, entre outros, acerca da inautenticidade da arte popular. Nesta perspectiva dicotômica e pejorativa, o autor enfatiza que os prazeres, as sensações e as experiências que a arte popular pode proporcionar são rejeitados e entendidos como falsos e enganosos, enquanto o suposto prazer estético provindo das artes elevadas é, ao contrário, tido como fonte de legitimidade. Drogas, doença, hedonismo, masturbação e prazer sexual precoce são alguns dos comparativos que os respeitados intelectuais usam para difamar a arte popular, relegando-a a um plano do imundo e do impuro, do qual, supostamente, apenas prazer, sexo e corpo fazem parte. Assim, propaga-se uma perspectiva ascética, simultaneamente platônica/marxista/cristã, com expoentes como Bloom, Adorno e Van den Haag, que não tolera os prazeres ditos elevados, e muito menos os populares, pregando que os únicos prazeres a serem almejados são aqueles impossíveis de se alcançar neste mundo. 
Nesta perspectiva dicotômica, na relação com produtos da arte popular/cultura de massa, de acordo com Shusterman (1998), o prazer leva ao tédio e não exige esforço intelectual algum, apenas meras associações. O produto, artefato, obra - da arte popular - já prescreve a reação a ser tomada, sendo evitada qualquer conexão lógica ou mental, conforme afirmam Adorno e Horkheimer. Shusterman (1998) expressa que boa parte da crítica desses intelectuais procede, mas, também, dela emerge uma "confusão simplista" (p. 118) entre o que se chama de atividade legítima e pensamento sério, esforço qualquer e esforço mental do intelecto. Essas críticas em relação à arte popular consideram as atividades e operações humanas do ponto vista estético, do prazer, do afeto, como se estivessem separadas daquilo que chamam de esforço intelectual. Ainda segundo Shusterman (1998), Adorno considera a música pop regressiva, inválida do ponto de vista estético, pelo fato de constituir um estímulo somático. Do mesmo modo, para Bloom, o rock apela à sensualidade e ao desejo sexual, o que hostiliza a razão. Remonta-se por essas vias, o já conhecido embate e consequente separação entre corpo e mente, inteligibilidade e sensibilidade, razão e emoção, arquitetadas por Platão na Grécia antiga, cristianizadas por Santo Agostinho na idade média e reiteradas por Descartes na modernidade.

Numa compreensão que a nosso ver apresenta traços dicotômicos, Shusterman (1998) tece a seguinte distinção: "no nível somático, há muito mais atividade e esforço na apropriação do rock do que na música erudita" (p. 118). Nessa visão, o rock se configura como movimento, dança e canto com esforço vigoroso que provoca suor e exaustão. A música erudita, por sua vez, é constituída na disciplina dos acentos, do silêncio e da imobilidade, que podem levar à passividade e ao sono.

Associamos esta reflexão ao show pop de Madonna e ao espetáculo de dança contemporânea de Pina Bausch. Uma, a estrela pop que se apresenta em estádios, arrancando gritos, cantos, coreografias e muito suor da legião efusiva de fãs. A outra, a diva germânica que apresenta seus espetáculos em requintados teatros, comove olhares, provoca suspiros, motiva lágrimas, críticas, teses e dissertações no público sentado e silencioso perante seu espetáculo. A pergunta parece retórica, mas pode disparar a reflexão: Como as duas artistas envolvem ou estimulam o "nível somático" apontado por Shusterman? Uma resposta imediatista pode conduzir a um engodo crítico que em vez de atenuar, perpetua as disparidades entre arte popular e arte elevada, corpo e mente.

Nem Madonna, nem Pina Bausch dispensam o envolvimento e estímulo somático, pensamos nós. Conforme as discussões apresentadas acima, da filosofia na carne e do corpomídia, um gesto ou uma ideia exigem tanto funções mentais quanto físicas, sem separá-las. Ou seja, pensar e se mover são ações do corpo que provém dos mesmos 
procedimentos sensório-motores e conceitual-abstratos que agem indissociadamente, sempre. Por mais que para pular, erguer os braços e gritar diante do show de Madonna movamos mais músculos e órgãos do que para chorar, suspirar e ter ideias para escrever um artigo perante uma coreografia de Pina Bausch, isso não quer dizer que usamos mais o corpo no show de Madonna e mais a mente no espetáculo de Pina Bausch. Isso não quer dizer que sentimos mais prazer com Madonna do que com Pina. E, igualmente, isso não quer dizer que fomos mais engajados/ativos com Madonna e mais contemplativos/passivos com Pina. Corpo e mente, emoção e razão, sentimento e pensamento, sensível e inteligível, atuam juntos, em ambas as situações, sem qualquer hierarquia e necessidade de distinção.

Para Shusterman (1998) "as artes populares [...] sugerem uma estética radicalmente revisada, com um retorno alegre e impetuoso da dimensão somática que a filosofia reprimiu" (p. 119) em função da supremacia do intelecto. Esta afirmação nos intriga. De fato, a filosofia analítica ocidental tem afirmado uma finalidade racionalista para a estética em detrimento do corpo, do prazer e do afeto. Mas o que significa dizer que a arte popular promove a volta do corpo dançante e vibrante antes reprimido? Como essa afirmação poderia estar proclamando a arte popular como a heroína que salva o corpo das prisões do intelectualismo? Como o discurso que relega a arte popular ao domínio do corpo (inferior) em função da arte erudita estar no plano da alma/mente (superior) pode estar sendo mantido em vez de criticado?

Entendemos, a partir das compreensões de Lakoff e Johnson (1999), Greiner e Katz (2005) que mesmo esse discurso filosófico tradicional que reprime o corpo foi e é (re)criado, articulado, comunicado, ouvido e propagado por corpos, pelos corposmídia, pela indissociabilidade corpo/mente e não por uma mente ou razão descorporificadas, embora ele assim pretenda. Nesse sentido, então, mais adiante em sua reflexão, Shusterman (1998) comenta que a sensorialidade instigada pelo rock não implica um antiintelectualismo ou uma ausência de pensamento e interpretação. Se alguns apreciam rock, e pop, nós acrescentamos, de modo superficial, isso não quer dizer que essa suposta superficialidade seja deflagrada pelo produto rock, ou, pelo prazer sensorial que ele pode estimular. O prazer ou o desprazer que o rock ou o pop podem gerar não estão, necessariamente, desprovidos de razão. Pelo contrário, pensamento e sentimento estão continuamente se entrecruzando quando o corpo articula suas percepções, impressões, reflexões e opiniões. Shusterman (1998) diz que nós somos "intelectos sensuais" (p. 120) e que tais separações (corpo e mente, sentimento e pensamento) são inépcias que só teriam sentido caso houvesse incompatibilidade entre o sensorial e o intelecto, o que bem sabemos, não há. Há sim a compatibilidade que os entrelaça. 
Olhar um quadro de Monet, ouvir uma sinfonia de Beethoven, ver um anúncio de cuecas, assistir um espetáculo de Pina Bausch ou cantar e dançar efusivamente com uma canção de Madonna, envolvem o corpomídia e todas as suas ações de pensar, sentir, se mover, etc. Não é a diferença entre a quantidade de músculos empenhados, de batimentos cardíacos acionados ou de gotas de suor escorridas que restringem a relação pessoaartefato com a dita dimensão somática. De certa forma, a afirmação de que a arte popular confere uma estética com retorno da dimensão somática reprimida, em vez de flexibilizar fronteiras, pode acirrar e demarcar ainda mais locais e corpos distintos para as ditas arte popular e arte elevada. Em ambas, há o empenho e a atividade constante do corpo com sua mente.

Não é exacerbando na arte popular aquilo que a arte erudita nega - o corpo - que as dicotomias entre ambas serão atenuadas. Não é fazendo gritar o corpo aqui embaixo, que a mente lá em cima vai se abalar e vir piedosa e arrependida ao encontro da integração. Mas, quem sabe, tornando visível que não há corpo separado da mente. $\mathrm{E}$, ainda, que são os diferentes sujeitos - corposmídia - que criam, produzem, consomem, usam, amam ou repelem os artefatos culturais chamados de eruditos ou populares. Quem divide e separa são os discursos que os corpos concebem, propagam e inventam, não os produtos em si. Como, então, poderíamos perceber, nos diferentes usos que os corpos fazem desses produtos culturais, formas de subverter os discursos divisores?

\section{Pina Bausch e Madonna: visualidades contempoprâneas}

Nas descrições de Cypriano (2005) acerca da visita de Pina Bausch ao Brasil, em Salvador/BA, entre os locais visitados estão: a casa de pagode Língua de Prata, a Feira de São Joaquim, a Igreja do Bonfim, o Pelourinho, a Igreja de São Francisco, a apresentação do Olodum e da Timbalada, o Mercado Modelo, o projeto artístico e social de Carlinhos Brown na favela do Candeal, a praia do Rio Vermelho, uma roda de capoeira na casa do Mestre Curió, o terreiro da Mãe Menininha do Gantois. O autor comenta que "é essencialmente nas camadas populares e marginalizadas que se encontra o ambiente de estímulo para a criação das peças de Bausch" (p. 100).

Chama atenção o modo como Cypriano (2005) busca enfatizar o popular no olhar da coreógrafa para o Brasil, distinguindo os locais que ela visitou em Salvador. O autor ressalta esta visão ao afirmar que "a relação entre o erudito e o popular é a base da forma de observação de Bausch, uma artista interessada na gente das ruas, nas manifestações com raízes populares" (p. 100). A forma como o autor tenta descrever o olhar de Bausch em relação ao popular nos parece mais romântica do que seria propriamente o olhar da coreógrafa. Ao empregar expressões como 'gente das ruas', 'raízes' e 'marginalizados', 
Cypriano (2005) parece acentuar uma conotação de um popular ingênuo, anônimo, sensível, espontâneo e perdido na coletividade, como o faziam os românticos descritos por Ortiz (1992).

Cypriano (2005) ressalta que a única exigência da coreógrafa foi conhecer locais populares, com muita gente. Segundo ele, Bausch salientou: "O que me interessa é a vida real, não busco representações dela, pois são obras já prontas e eu tenho de concentrar-me na minha própria obra" (p. 93). Mesmo tendo sido conduzida a alguns locais turísticos e representativos, Bausch buscava observar e sentir os tipos humanos. O que ela via, o fato/situação como tal, poderia não ter utilidade cênica, enquanto caricatura. Mas as sensações e percepções que ela captava e criava no contato com tais ambientes e corpos, concentravam seus interesses. Acerca da insistência de Bausch em permanecer observando por mais tempo na casa de pagode Língua de Prata, o dançarino Jorge Puerta comentou: "no palco, é essa energia que será vista, não a própria situação de maneira alegórica" (CYPRIANO, 2005, p. 95).

Se comparadas a obras de antigos artistas-viajantes europeus, as projeções de imagens gigantes da natureza, fauna e flora brasileira, utilizadas como cenários do espetáculo "Água", é possível encontrar analogias com aqueles olhares exóticos, representando as belezas naturais do Brasil. Esta visão romântica pode ser atrelada ao olhar de Peter Pabst, cenógrafo que trabalhava com Pina Bausch e que relatou: "Eu preciso entrar em contato com a natureza, não sou como Pina que prefere observar as pessoas nas ruas" (CYPRIANO, 2005, p. 99). O espetáculo não reproduz caricaturas da feira, do pagode, da capoeira, do candomblé, tampouco da missa que estava sendo rezada na Igreja de São Francisco enquanto a coreógrafa e os dançarinos faziam sua visita. Entre os movimentos e gestos, criados com afetos, sensações e percepções emergidos da relação com os ambientes visitados, e as projeções tecnológicas das belas imagens da fauna e flora brasileiras, temse um produto artístico-cultural contemporâneo que mistura diferentes visões, afetos, imagens e aparatos tecnológicos em seu processo de criação.

Diferentemente dos relatos de Cypriano (2005) sobre o espetáculo "Água", não se tem informações acerca dos procedimentos criativos do show "MDNA Tour" de Madonna.

Entretanto, o que percebemos na apresentação de Madonna são visualidades que possibilitam uma identificação mais rápida entre o produto artístico e suas possíveis referências, ou seja, uma missa ou celebração religiosa católica. No caso de Bausch, a suposta referência ao candomblé nos movimentos coreográficos pode passar tranquilamente despercebida aos olhos do público que nada sabe do seu processo criativo. A imagem vista no núcleo águas místicas de "Água", no conjunto de cenografia, objetos, figurinos, personagens e gestualidade, não remete diretamente a um terreiro de 
candomblé. Porém, no show de Madonna, a imagem de um ato religioso cristão-católico é deliberadamente construída, tornando as referências visíveis, para quem conhece o culto. Essa constatação não exalta uma pretensa e elevada erudição de Pina Bausch e uma suposta e simplória popularidade de Madonna. Um olhar imediatista pode levar ao entendimento de que a obra de Pina Bausch demandaria maior complexidade estética, um árduo exercício do intelecto, um intenso investimento da mente e um uso específico da racionalidade para tecer relações entre as minúcias gestuais e as danças do candomblé de Salvador. O show de Madonna, numa compreensão inversa, funcionaria através de associações, visto que, em meio à euforia e a estimulação da sensorialidade e do prazer corporais, a imagem da celebração católica se dá à percepção como algo reconhecido que, pela força do rito, não se concentra em exigências de esforço intelectual. Assim como Adorno e Horkheimer já sublinharam em outros contextos, poderíamos classificar Pina Bausch como arte erudita, um domínio da mente e, Madonna, como arte popular, um domínio do corpo.

Se olharmos para os mesmos artefatos culturais, porém agora focando os atos religiosos nos quais eles se referenciam, compreensões diferentes podem emergir. Pina Bausch traz referências do candomblé, a religião das negras e negros africanos, presos, torturados, distanciados de suas terras e escravizados no Brasil. Os terreiros que ainda existem são meios de manter viva sua cultura, são espaços para cultivarem seus afetos e valores. 0 racismo, o preconceito e as desigualdades sociais colocam os negros numa situação de marginalização. Já o que se vê na performance de Madonna é um rito católico com elementos góticos e gregorianos que simbolizam as vertentes mais conservadoras dessa instituição que ainda domina o cenário mundial e que abençoou a morte e a escravidão de negros e índios, além de excluir as mulheres de sua hierarquia machista e taxar como anomalia a homossexualidade. Vendo sob esta perspectiva poderíamos dizer que o espetáculo de Pina Bausch tem um cunho popular/menor/marginal e a performance de Madonna um cunho erudito/elevado/dominante?

Prosseguindo o reposicionamento de olhares e modos de ver, na apresentação de Madonna, especificamente a canção "Girl Gone Wild", ("garota ensandecida" ou "garota que perdeu o controle, o juízo"), assistimos uma movimentação transviada dos monges, despindo-se das túnicas e dançando trejeitos queer, de sapatos de salto alto. São imagens de ironia e transgressão (imagem 1), aproximáveis daquelas das águas festivas de Pina Bausch, quando os dançarinos estão em trajes de banho à frente dos sofás brancos e metamorfoseiam suas formas e gêneros brincando com imagens reproduzidas em toalhas (imagem 2). Em ambas as imagens - a de clima carnavalesco e a de clima pop sensualidade, insinuação, desejo e sedução envolvem tanto os corpos dançarinos quanto 
os corpos espectadores, ao vivo, ou, por meio de imagens. São imagens de inversões e subversões que podem interpelar e tirar o olhar de certas visões cômodas e determinadas acerca do corpo, desejo, afeto, gênero e sexualidade, às quais estamos acostumados.

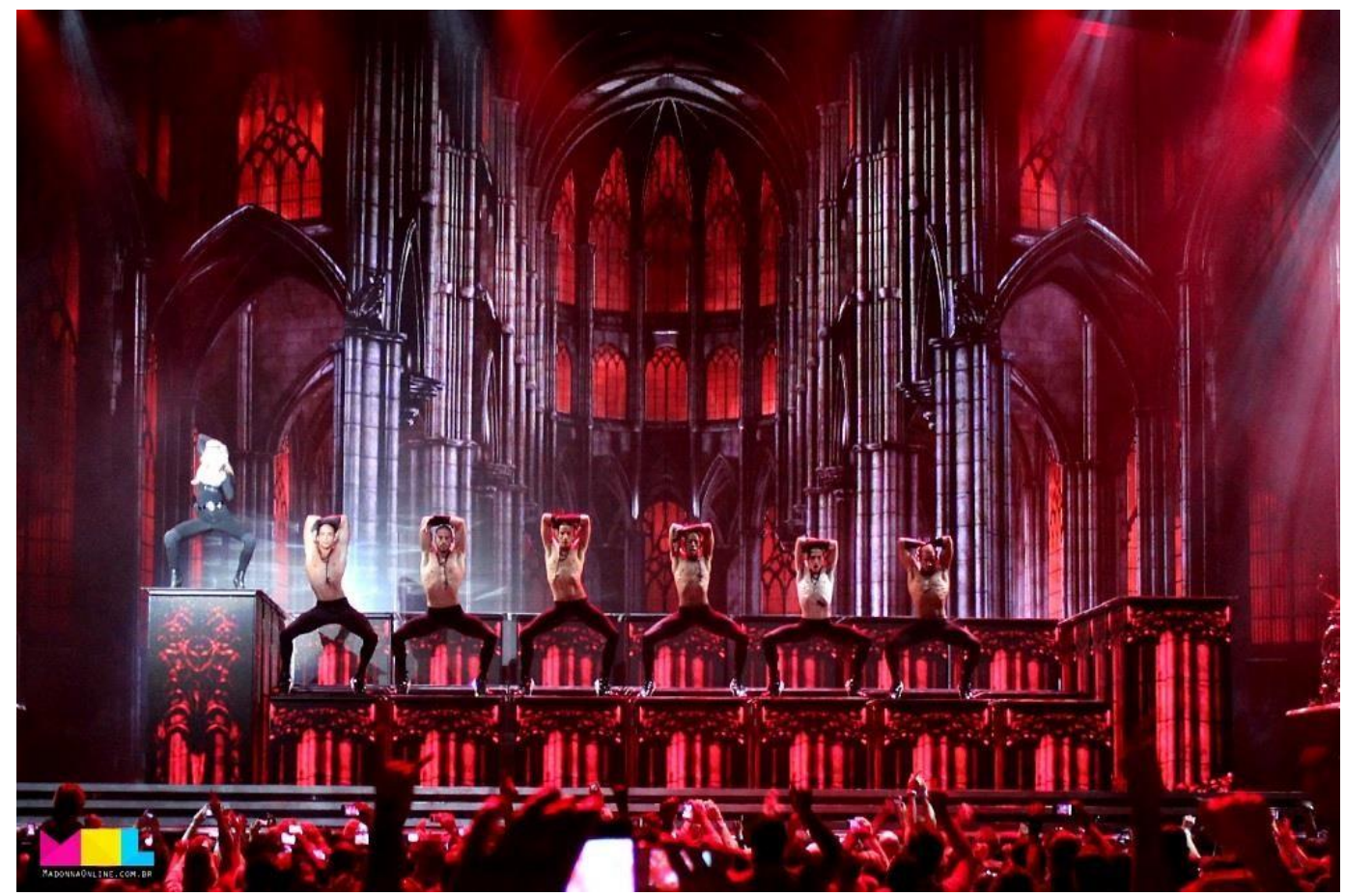

Imagem 1

Performance "Girl Gone Wild", MDNA Tour (2012), de Madonna.

<http://madonnaonline.mtv.uol.com.br/page/2/?s=estreia+MDNA+Tour+Tel+Aviv\& $=10$ \& y=12> Acesso em 05 jul. 2012. 


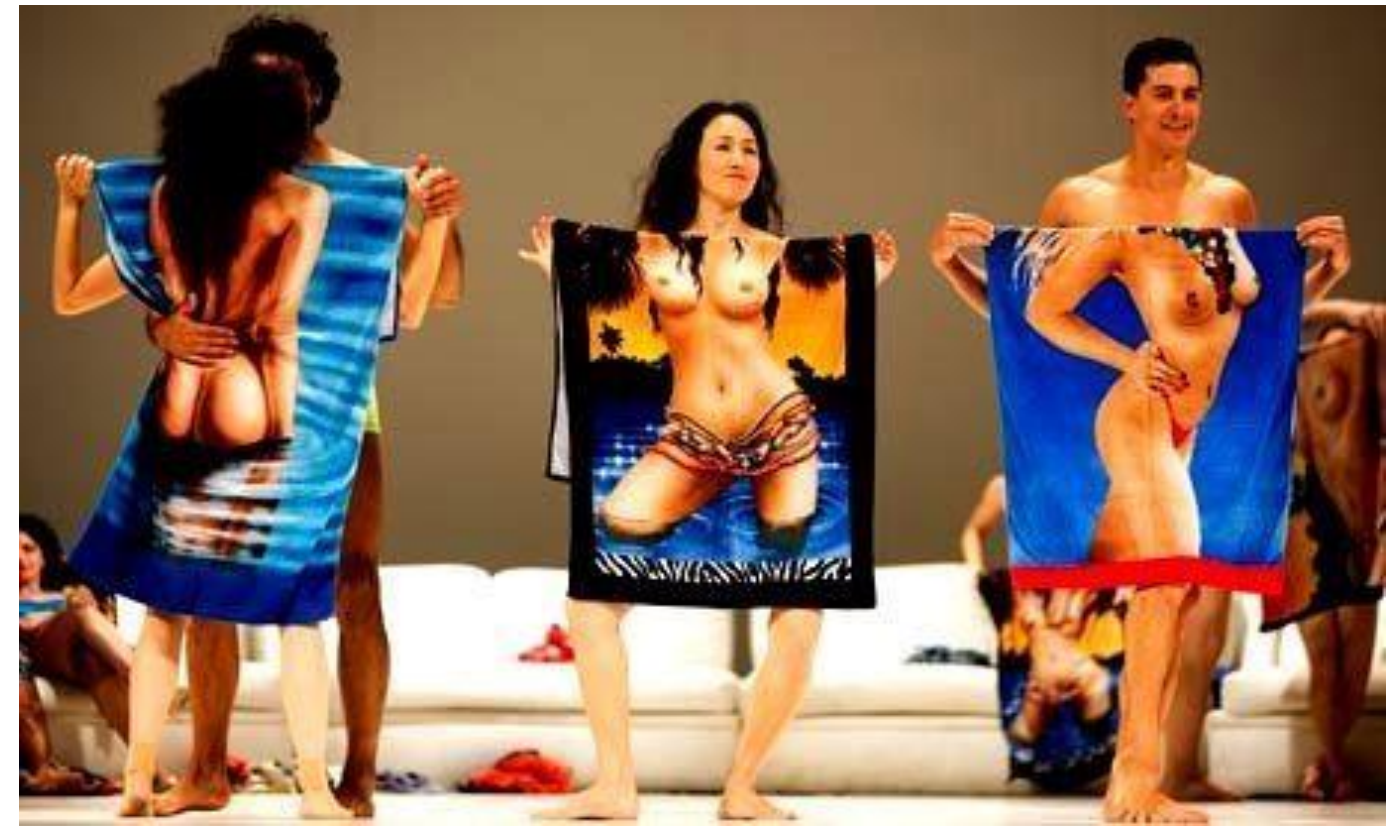

Imagem 2

Cena do Espetáculo "Água" (2001) de Pina Bausch. Foto de Murdo Macleod. <http://www.guardian.co.uk/stage/2010/sep/05/agua-charlatan-edinburgh-festival-dance> Acesso em 05 jul. 2012.

Retornamos às belas imagens dos dançarinos se movendo entrelaçados com as projeções dos pássaros em voo no bloco águas sensuais de "Água". Segundo Cypriano (2005), esta proposta acontece não tanto como princípio estético, mas com intuito de proporcionar prazer. "Em Água, o humor está presente principalmente nos jogos de sedução" (p. 117), demarcando uma das características desejadas pela coreógrafa ao afirmar: "Para mim, o que realmente é necessário é ver certas ironias, rir de alguma coisa, ter um certo prazer" (CYPRIANO, 2005, p. 117). Entre ver e sentir a beleza das imagens que misturam projeções e dança em cenas de sedução e afeto, e rir perante imagens irônicas e cômicas, o prazer é destacado como algo a ser proporcionado no diálogo com o espectador.

Entendemos essas imagens de Madonna e Pina Bausch, entre tantas outras, como visualidades contempoprâneas, ou seja, um conjunto de corpos, performances, modos de ver e ser visto, ações artísticas e comerciais, artefatos e imagens, em constante circulação e (re)invenção, produzidos/consumidos/mediados entre relações de afeto, prazer e poder e ambientados num intercambio natureza/cultura. São visualidades que entrecruzam temporalidades, lugares e objetos, borram distinções como erudito e popular, corpo e mente, sensível e inteligível, podendo dissimular modos tácitos de ver e perceber, mostrando desejos, prazeres e afetos da e na imagem assim como os que permeiam a relação do corpo com as imagens. São esses desejos, afetos, fascínios e seduções que permeiam as aproximações, afeições, imaginações, reflexões, análises e escritos que 
surgem da relação e do contato com tais imagens e performances. São relações corporais permeadas pelo prazer e pelo afeto.

\section{Entre prazeres e usos de visualidades contempoprâneas}

Com estes contrastes e aproximações, vislumbramos possibilidades de sair dos binômios arte erudita e arte popular e avançar para um entendimento, ou modo de ver flexível e abrangente, próximo do que propõe Giroux (1999). Este autor destaca que não há como entender a "cultura popular fora dos processos entrosados de significado, poder e desejo que caracterizam a força das relações culturais" (p. 220) que agem num tempo e lugar determinados na história. Nesse contexto se misturam produtos e artefatos ditos populares, menores, eruditos, de massa, dominantes, etc., que não estão fixos nos limites do binômio popular e erudito. O popular, nessa perspectiva, não é uma classificação, mas é um conjunto de práticas, discursos e combinações de significados corpóreos e ideológicos que produzem efeitos afetivos. Tais significados, conforme as reflexões anteriores, não se dão separadamente, pois as ideologias agem nos corpos da mesma forma que são criadas por eles. O modo como as formas da cultura popular são mediadas e assumidas tem como terreno o prazer. Para Giroux (1999),

a cultura popular representa um local histórico particular onde grupos diferentes colidem em transações de dominação, cumplicidade e resistência em relação ao poder, para nomear, legitimar e experimentar diferentes versões da história, da comunidade, do desejo e do prazer [...]. (p. 221).

Giroux (1999) segue comentando que na relação com determinadas formas culturais populares, as necessidades, paixões e emoções dos sujeitos ressoam as estruturas materiais e ideológicas da vida cotidiana. Nessas relações encontra-se um investimento de diversão e envolvimento afetivo em que não há disjunção/interrupção entre o ato e seu significado. Nesse conjunto ativo de experiências e práticas sociais há "uma forma de participação pública em que a prática dominante de se distanciar o corpo da reflexão é recusada. Este é o momento produtivo da corporalidade" (p. 222). Tanto as formas culturais que mobilizam desejo e afeto como as lutas que ocorrem pela reprodução do investimento do desejo, do prazer e do corpo, são construídas no campo das relações de poder. O corpo pode ser inscrito em ações repressivas ou emancipatórias e, nesse sentido, o autor destaca o quão necessário é um conjunto de práticas e discursos que reconheçam a sensibilidade e os modos como se dá social e culturalmente a produção dos corpos.

De Certeau (1994) reflete no sentido de que as práticas populares não devem continuar sendo entendidas como carcerárias de um passado, de uma primitividade ou de modelos 
operatórios de uma pretensa cultura popular. Tais práticas "existem no coração das praçasfortes da economia contemporânea" (p. 87). O que se poderia chamar de cultura "popular", continua o autor, são: estilos de trocas sociais, de invenções técnicas e de resistência moral; uma economia do "dom"; uma estética de "golpes"; uma ética da tenacidade. Diante dos produtos disponíveis no mercado artístico e cultural, imagens, roupas, filmes, músicas, danças e outros artefatos, De Certeau (1994) enfatiza as práticas de uso, seu movimento sub-reptício e astucioso, a atividade do "fazer com", as trajetórias táticas que "selecionam fragmentos tomados nos vastos conjuntos da produção para a partir deles compor histórias originais" (p. 98).

Para De Certeau (1994), as estatísticas calculam e enumeram unidades, palavras publicitárias, imagens televisivas, lugares construídos e produtos vendidos. Contabilizam o que é usado, mas não os diferentes modos de usos que são feitos. Dessas práticas sorrateiras, insinuantes e deslizantes que se espalham por toda parte, só são tornados visíveis, não a qualidade das formas de uso, mas a quantidade e a localização dos objetos consumidos. Nesse sentido, como pensar o entrelaçamento das visualidades contempoprâneas com as práticas cotidianas? Como pensar os modos como essas visualidades conformam as identidades/identificações dos corpos? Que usos dessas visualidades seriam possíveis no sentido de articular procedimentos pedagógicos?

\section{Visualidades contempoprâneas, pedagogias do corpo}

No contexto da reflexão sobre divisão do sensível, política e estética, Aguirre (2011) propõe que a cultura visual está em condições de mudança e assim pode avançar de uma posição fundamentada na "valoração crítica da cultura a outra que deixe espaço à diversidade dos usos e experiências, incluindo os relacionados ao afetivo e ao sensível" (p. 72). As proposições deste autor se dão em torno da recuperação das questões emotivas e afetivas, um desafio educativo que, segundo ele, pode provocar rupturas nas configurações dos espaços e tempos do ver e do dizer, bem como, gerar dissensos nas políticas da estética hegemônica.

Com sua reflexão acerca dos produtos da cultura popular no ambiente da pedagogia crítica, Giroux (1999) propõe possibilidades que avancem para a consideração da experiência dos educandos moldada no terreno da cultura popular. O autor aponta a necessidade de se conhecer e valorizar, para além dos significados que os educandos constroem em relação ao conteúdo de sala de aula, as formas culturais e sociais que são consentidas por eles, que os capacitam ou os incapacitam. Dialogar com artefatos culturais que educandos consomem e que, portanto, conformam seus sentidos de identidade/identificação, política e cultura, pode gerar condições de aprendizagem onde eles venham a interrogar seus 
próprios modos de usar tais produtos não tornando-se apáticos diante deles e das relações de poder que os envolvem.

Giroux (1999) propõe uma pedagogia que vincule o conhecimento da escola com as relações que constroem as vidas cotidianas dos alunos. A partir dessa proposta e das abordagens da educação da cultura visual, imaginamos uma pedagogia que não apenas busca vincular os conhecimentos da escola com as práticas cotidianas dos educandos. Pensamos uma pedagogia contemporânea que entende e torna visível que o cotidiano não é só o dia a dia frugal no quintal de casa e os momentos de entretenimento diante da TV ou junto à família enquanto isolados das demais vivências e interações. Mas, o conjunto natural/cultural que constitui a vida de um sujeito - corpomídia - em sua relação com o ambiente pelo qual é contaminado e do qual é contaminador. Nesse modo de compreender, a escola e seus conhecimentos não devem ser vinculados, pois já fazem parte do(s) cotidiano(s) do educando. Assim, entendemos que afetos e prazeres que constituem as relações dos indivíduos com músicas pop, com anúncios de roupa, com imagens pornográficas ou quaisquer outros artefatos, não ficam do lado de fora quando eles e elas estão na sala de aula. Estão ali, no mesmo corpo que se relaciona com conteúdos enfadonhos muitas vezes desprovidos de prazer, ou que achatam os prazeres. São problemáticas essas concepções dicotômicas, dualistas e modernistas que operam no sentido de invisibilizar esse enredamento do cotidiano do qual a sala de aula já é parte, vínculo que já existe entre os conhecimentos e seus âmbitos de referência, a escola e as demais ações e relações do corpo em seu ambiente.

Conforme Giroux (1999), evidenciamos que o desafio consiste em, diante da diversidade de ofertas de produtos, imagens e personagens que colorem o cenário atual, ou seja, diante de tantas e sedutoras visualidades contempoprâneas, criar uma pedagogia sensível às maneiras como os educandos tecem seus investimentos afetivos e semânticos para articular suas identificações e dar significado às suas vidas. Esta perspectiva abrange a construção de uma prática educativa que, expandindo as potencialidades humanas, possibilita a transformação das condições ideológicas em práticas sociais de empoderamento para os sujeitos intervirem na formação de suas subjetividades. Nesse sentido, o vasto terreno cultural/natural da vida cotidiana, que abarca as relações educativas, afetivas, sexuais, sociais, econômicas, religiosas, etc., é entendido como o lugar onde a produção de subjetividades pode ser vista como um processo políticopedagógico.

Questionando os modos como a aprendizagem tem desmerecido o desejo e o prazer, em função da supremacia do racionalismo e do discurso, Giroux (1999) diz que a pedagogia não é isenta na produção do discurso e que ela 
também constitui um momento em que o corpo aprende, se movimenta, deseja e anseia por afirmação. Essas indagações também sugerem uma rejeição da pedagogia da modernidade [...] que serve a formas "ideais" da teoria da comunicação, em que a tirania do discurso torna-se o meio pedagógico fundamental, ou seja, a conversa incorporada como uma lógica abstraída do próprio corpo. (p. 226).

O autor enfatiza que esta não é uma tentativa de privilegiar o corpo ou uma política de investimentos afetivos sobre o discurso. Mas, uma tentativa de enfatizar os modos como o corpo tem estado ausente dessas teorizações e, também, uma tentativa de destacar a importância do corpo para uma pedagogia crítica. Giroux (1999) afirma que o prazer deve ser visto, pensado e experimentado politicamente, para que assim se possa tecer uma análise crítica de "como o corpo se torna não somente o objeto do [seu] prazer [patriarcal], mas também o sujeito do prazer. Nesse caso, o prazer torna-se o consentimento da vida no corpo" (p. 228). Corpo, afeto e prazer se tornam categorias importantes para compreender relações que educandos constroem para e com as diferentes imagens, artefatos e performances culturais.

No contexto da chamada virada imagética, Aguirre (2011) discute acerca da relação entre estética e política, multiplicação das imagens e suas consequências na vida pública, apontando os efeitos deste regime de visualidade na estetização da vida cultural como um desafio à educação da cultura visual. Se a estética consegue impor significados aos objetos e os transformar em conceito, a ponto de exercer influência sobre corpos e seus modos de vida, ela pode, então, se tornar, também, um procedimento para criar estratégias de ativação do desejo, o que pode ser visto como um ponto crítico e desafiador para a educação, a arte, a cultura visual (AGUIRRE, 2011). Esse desafio instiga propostas educativas pautadas nas possibilidades que a cultura visual apresenta para a formação de corpos sensíveis, críticos, éticos e ousados para "romper com os regimes do sensível imposto pela política estética herdada da modernidade" (AGUIRRE, 2011, p. 92).

Seja por meio das águas de Pina Bausch, em seus modos de ver o Brasil, pela missa profana de Madonna ou de outras formas de visualidades contempoprâneas, a proposta de considerar as experiências dos educandos não requer que os educadores abandonem o que e como eles sabem. A interpelação, conforme Giroux (1999), consiste em articular espaços para o entrecruzamento das diferentes experiências vividas. Tornar as performances culturais, ou o que chamamos de visualidades contempoprâneas, objetos de estudo, é arriscar trabalhar com educandos um discurso e uma forma de análise distante da ideia de pedagogia adequada à qual eles estão acostumados. Ou, ainda, arriscar reconstituir significados, prazeres e discursos formatados pelas ideologias de mercado, as quais produzem e manipulam muitas das visualidades contempoprâneas. 
Por isso, trata-se de um desafio pedagógico e não de uma receita de dinâmicas didáticas.

\section{Outros modos dos corpos (se) (mo)verem}

Entrecruzando visualidades contempoprâneas de Pina Bausch e Madonna, esta reflexão extravasa as fronteiras classificatórias entre música pop, cultura de massa, dança contemporânea, arte popular, arte erudita, etc., visando articular outras práticas de uso e movimentos corporais afeitos à seleção de fragmentos da experiência vivida para a invenção de outras histórias de/com o corpo.

Desse modo, propomos pensar-fazer uma pedagogia que se entende como parte do(s) cotidiano(s) - ambiente natural/cultural - dos corpos e não como uma esfera superior iluminada que almeja criar vínculos com o suposto cotidiano simplório e frugal dos (a)lunos = sem luz. Uma pedagogia que, sensível ao corpo, ao prazer e à afetividade, busca entender os modos como educandos investem seus afetos nas performances culturais e visualidades contempoprâneas. Buscamos, ainda, incentivar práticas de uso e invenção de narrativas, imagens, artefatos, gestos, movimentos, etc., como formas de empoderamento e postura crítica, sensíveis e prazerosas. Diferentemente das formas dicotômicas e modernistas, estas práticas podem criar outras formas dos corpos (se) (mo)verem.

\section{Referências}

AGUIRRE, I. Cultura visual, política da estética e educação emancipadora. In MARTINS, R.; TOURINHO, I. (Org.). Educação da cultura visual: conceitos e contextos. Santa Maria: UFSM, 2011.

ALVES, Rubem. Variações sobre o prazer: Santo Agostinho, Nietzsche, Marx e Babette. São Paulo: Editora Planeta, 2011.

CHAUÍ, M. A posição do agente da liberdade na ética V. In: CHAUÍ, Marilena de Souza. Cadernos Espinosanos: estudos sobre o século XVII. São Paulo: Departamento de Filosofia da FFLCH-USP, N. XXII, Jan-Jun de 2010.

CYPRIANO, F. Pina Bausch. São Paulo: Cosacnaify, 2005.

DE CERTEAU, M. A invenção do cotidiano: 1 artes de fazer. Petrópolis, RJ: Vozes, 1994. GIROUX, H. Cruzando as fronteiras do discurso: novas políticas em educação. Artemed: Porto Alegre, 1999.

GREINER, C; KATZ, H. Corpo e processos de comunicação. In Revista Fronteiras: estudos midiáticos. São Leopoldo: UNISINOS, Vol. 3, n. 2, p. 65-75, dez. 2001. Por uma 
teoria do corpomídia. In: GREINER, Christine. O corpo: pistas para estudos indisciplinares. São Paulo: Annablume, 2005.

LAKOFF, G.; JOHNSON, M. Philosophy in the flesh: the embodied mind and its challenge to western thought. New York: Basic Books, 1999.

ORTIZ, R. Românticos e folcloristas. São Paulo: Olho d'água, 1992.

SHUSTERMAN, R. Vivendo a arte: o pensamento pragmatista e a estética popular. São Paulo: Editora 34, 1998.

Odailso Berté (FAV/UFG)

Raimundo Martins (FAV/UFG)

Irene Tourinho (FAV/UFG)

Recebido em: 04/12/2012

Aprovado em: 15/01/2013 